\section{Assessing a local food system: The Palouse-Clearwater Food Coalition assessment process}

\author{
Allison Bauman a \\ Colorado State University \\ Colette D ePhelps ${ }^{b}$ \\ University of Idaho Extension \\ Dawn Thilmany McFadden ${ }^{*} *$ \\ Colorado State University
}

Submitted April 3, 2018 / Revised July 20 and August 28, 2018 / Accepted August 28, 2018 /

Published online January 9, 2019

Citation: Bauman, A., D ePhelps, C., \& Thilmany McFadden, D. (2019). Assessing a local food system:

The Palouse-Clearwater Food Coalition assessment process. Journal of A griculture, F ood Systems, and

Community D evelopment, 8(Suppl. 3), 107-118. https:/ / doi.org/ 10.5304/ jafscd.2019.08C.008

Copyright (C 2019 by the Authors. Published by the Lyson Center for Civic Agriculture and Food Systems. Open access under CC BY license.

\begin{abstract}
This case study features the Palouse-Clearwater Food Coalition, an alliance of individuals, community organizations, institutions, agencies, nonprofits, and businesses with a shared interest in developing the local food system in southeastem

a Allison Bauman, D epartment of Agricultural and Resource Economics, Colorado State University; Clark B-320; Fort Collins, CO 80523 USA; allie.bauman@ colostate.edu

b Colette D ePhelps, Area Educator, Northern District Extension, University of Idaho; 875 Perimeter D rive MS 2338; Moscow, ID 83843 USA; cdephelps@uidaho.edu

c * C orresponding author: D awn Thilmay McFadden, D epartment of Agricultural and Resource Economics, Colorado State University; Clark B-310; Fort Collins, CO 80523 USA; dawn.thilmany@colostate.edu
\end{abstract}

Washington and north central Idaho. The aim of this case study is to demonstrate how a community coalition could utilize the tools in the U.S. D epartment of Agriculture, Agricultural Marketing Service's economic impact toolkit (Thilmany McFadden et al., 2016) to guide its ongoing local food system assessment efforts and to provide structure and direction to its assessment process. The overall goals of the Coalition's local food economic impact assessment are to (1) make

\section{Funding Disclosure}

We would like to acknowledge the U.S. D epartment of Agriculture, Agricultural Marketing Service for funding this research through agreement \#16-TMMSD-CO-001. Support from the Colorado Ag Experiment Station contributed to this work as well. 
meaningful use of existing data and studies; (2) identify gaps in data, then use the methods presented in the Toolkit to fill in critical data gaps to provide a more complete baseline picture of the region; (3) define and communicate what constitutes economic impact to community stakeholders within the construct of a local food system; (4) understand how data and economic impact principles can help identify leverage points in the local food system; and (5) use information about leverage points to strategically acquire and invest resources in food system projects and research that will strengthen the economic viability of the region.

The Moscow Farmers Market economic assessment is an example of how these goals aligned to influence results. This assessment documented the value of the city of Moscow's investment to the Moscow Farmers Market Commission and city council. As a result of this assessment, the city moved the farmers market management out of the city's arts department and funded a full-time community events and farmers market coordinator.

\section{Keywords}

Local Foods, Case Study, Economic Impact, USDA Local Foods Toolkit

\section{Introduction}

This case study features the Palouse-Clearwater Food Coalition (referred to the Coalition), an alliance of individuals, community organizations, institutions, agencies, nonprofits, and retail businesses with a shared interest in developing the local food system. The Palouse-Clearwater food system encompasses an eight-county region, including parts of southeastern Washington and north central Idaho. The objective of this case study is to demonstrate how a community coalition could utilize the tools presented in the U.S. D epartment of Agriculture (USD A), Agricultural Marketing Service's (AMS) 2016 publication, The E conomics of L ocal F ood Systems: A T oolk it to G uide Community D iscussions, A ssessments and Choices (herein referred to as the Toolkit) to guide its ongoing efforts in assessing its local food system by providing structure and direction to the assessment process.

The Coalition was formed in 2011 with the goal of strengthening the health and vibrancy of the Palouse-Clearwater food system by increasing production, distribution, and consumption of locally grown food and agriculture products. In 2012, the Coalition began working with faculty, students, and Cooperative Extension agents at the University of Idaho, as well as AmeriCorps VISTA members to conduct assessments of their food system. Multiple institutions, including the University of Idaho and the Latah Economic D evelopment Council, provided funding and leadership for the various studies.

While the Coalition and its members have collected extensive data on the food system, the early studies were not under a larger, umbrella assessment with a focus or goal in mind. Given their piecemeal nature, they also do not tell a whole or cohesive story of the food system. The release of the Toolkit in 2016 ushered in changes for these studies. At its release, the Coalition steering committee members discussed how the Toolkit could help them organize existing food system data, provide resources for gathering additional secondary data, and guide the Coalition through the process of conducting a more systematic economic assessment of the food system. Subsequently, the Coalition began using the Toolkit to understand the basic tenets of an economic impact assessment, including how to delineate assessment boundaries, best practices for incorporating primary and secondary data, and selecting key areas of their food system in which to invest resources. Using the Toolkit as a guide, the Coalition set the following overall goals for its current local food economic impact assessment efforts:

1. Make meaningful use of existing data and studies;

2. Identify gaps in data, then use the methods presented in the Toolkit to fill in these critical data gaps to provide a more complete baseline picture of the region;

3. D efine and communicate what constitutes economic impact to community stakeholders within the construct of a local food system;

4. Understand how data and economic impact principles can help identify leverage points 
in the local food system; and

5. Use that information to strategically acquire and invest resources in food system projects and research that will strengthen the economic viability of the region.

This article begins with background on the Coalition, including the organization's history, profile and current assessment activities. Next, we summarize previous community food assessments conducted by the Coalition and discuss how well they align with the recommendations presented in the Toolkit. The article concludes with a discussion of the Coalition's current work, prerequisites for successful food system assessments, and key next steps for strengthening the Palouse-Clearwater food system.

\section{Organizational History and Profile}

The Coalition began in 2011 as a group of University of Idaho Extension professionals and nonprofit partners conducting agricultural educational programs and research in Latah County, Idaho. It has since expanded, and now serves a rural, eightcounty region that includes parts of southeastern Washington and north central Idaho. The Coalition's members include individuals, community organizations, institutions, agencies, nonprofits, and businesses. Together these individuals and groups share the goal of strengthening the health and vibrancy of the Palouse-Clearwater food system by increasing production, distribution, and consumption of locally grown food and agriculture products. ${ }^{1}$ Since its inception, the Coalition's membership has grown its membership to over 100 organizational and individual members from across the eight-county region.

Early on, members of the Coalition realized they were all working to support local, small-scale agriculture and food systems, and that their stakeholders would be better served through a more collaborative and coordinated effort. While the group was in this process of formally organizing, several food system- oriented grants were awarded to organizations in Latah County and neighboring counties, including two grants to conduct a feasibility study for food processing centers located 35 miles apart. With two similar studies underway, the group wanted to collaborate on developing infrastructure that would serve a larger geographic region. The result was the adoption of an expanded geographic scope and regional approach by the Coalition.

The Coalition's steering committee first learned about the Toolkit in spring 2016 and immediately considered it as a guide for its ongoing efforts, particularly for the assessment process. For the remainder of 2016, a portion of each monthly Coalition meeting was devoted to discussions of how to strengthen these assessment efforts. As a result of these discussions, the Coalition decided to use its January 2017 Food Summit as an occasion to educate the community about current food system assessment activities. This summit also included a discussion of how local food can be a driver of economic and community development.

In spring 2017, the Coalition's steering committee - chaired by the newly hired University of Idaho community food systems area extension educator for north Idaho- began reviewing its existing food systems data and, consequently, redirecting assessment efforts. O ne of the priorities of this project was utilizing the data from previously conducted studies as a baseline for measuring change in the Palouse-Clearwater food system. Under the guidance of the Coalition chair, a half-time intern began using the Toolkit as a guide for collecting additional and updated primary and secondary data on the food system. The purposes of this endeavor were to develop informational graphics that would educate community members and policy-makers about the food system and economic impacts of specific local food businesses and initiatives, and to document how the Palouse-Clearwater food system has changed over time. Additional assessment activities included developing a geolocated map of primary food systems data, case studies on collaborations in the food system, and a newly funded USD A Agriculture and Food Research Initiative (AFRI) research project. This research project used past assessment data to identify a high-priority objective: removing

1 http:// www.pcfoodcoalition.org 
constraints to increasing fruit and vegetable production, such as access to land and water, on the Palouse. As an outreach partner on this USD A AFRI research project, the Coalition is now fortunate to be collaborating with University of Idaho faculty from the colleges of Agricultural and Life Sciences, Business and Economics, and Science, a team that is both knowledgeable about and interested in economic impact assessments.

While the Coalition is fiscally sponsored by Rural Roots, Inc., a local nonprofit organization, its food system economic assessment activities are indirectly supported by sources outside of the Coalition's annual budget. Subsequently, one of the main challenges the Coalition faces in its food assessment process is a lack of consistent and coordinated funding. Although the Coalition is very passionate about the food system and committed to conducting a thorough assessment, no one on the Coalition is being funded to conduct the assessment as a sole focus of their employment. While this has been a challenge, the Coalition has effectively leveraged existing resources, particularly those available through the University of Idaho, such as part-time interns, to enable the assessment process to continue.

\section{Previous Assessments}

Beginning in 2012, the Coalition began working with faculty, students, and Extension agents at the University of Idaho as well as AmeriCorps VISTA members to conduct more rigorous assessments of their food system. This section describes the strengths and weaknesses of data collected in previous assessments (including secondary and primary data) as well as a detailed discussion of the methods used to conduct an economic impact study. Each of the studies in Table 1 contributed to

Table 1. Previous Assessments Conducted for the Palouse-Clearwater Region

\begin{tabular}{|c|c|c|}
\hline Assessment & Data sources utilized in the study & Comments \\
\hline $\begin{array}{l}\text { Feasibility Study: Latah } \\
\text { County Food Innovation } \\
\text { and Resource Center } \\
(2013)\end{array}$ & $\begin{array}{l}\text { USDA Economic Research Service, Census } \\
\text { of Agriculture, US Bureau of Economic } \\
\text { Analysis, IMPLAN, Google Earth, a } \\
\text { producer survey, a purchaser survey. }\end{array}$ & $\begin{array}{l}\text { Maps utilized to effectively communicate } \\
\text { major differences in arable land that can be } \\
\text { found across this diverse region and highlights } \\
\text { the need for food systems development } \\
\text { strategies that are suited to this diversity. }\end{array}$ \\
\hline $\begin{array}{l}\text { Direct-to-Consumer Food } \\
\text { Markets in the North } \\
\text { Central Idaho Health } \\
\text { District (2014) }\end{array}$ & $\begin{array}{l}\text { Data sources include Idaho Department of } \\
\text { Public Health and Welfare, USDA NASSS } \\
\text { Idaho Agricultural Statistics, local econom- } \\
\text { ic development associations, US Census } \\
\text { Bureau, Idaho Office of Economic Develop- } \\
\text { ment, city-level comprehensive plans }\end{array}$ & $\begin{array}{l}\text { A combination of local and national level } \\
\text { secondary data sources used to tell the story } \\
\text { of direct-to-consumer markets in a regional } \\
\text { foodshed. }\end{array}$ \\
\hline $\begin{array}{l}\text { Food Security in the North } \\
\text { Central Health District of } \\
\text { Idaho (2014) }\end{array}$ & $\begin{array}{l}\text { U.S. Census Bureau's American } \\
\text { Community Survey, InfoUSA, USDA's Food } \\
\text { Supplemental Nutrition Assistance } \\
\text { Program Retailer Locator, GIS data, } \\
\text { Stakeholder Surveys }\end{array}$ & $\begin{array}{l}\text { Effectively utilized a combination of primary } \\
\text { and secondary data. Results from primary } \\
\text { data collection used as a means by which to } \\
\text { provide context to the conclusions drawn from } \\
\text { secondary data analysis from a local policy } \\
\text { standpoint. }\end{array}$ \\
\hline $\begin{array}{l}\text { Extensive database of food } \\
\text { producers, vendors, } \\
\text { markets, and organizations } \\
\text { including interconnections } \\
\text { of who sells to whom }\end{array}$ & $\begin{array}{l}\text { Primary data collected from food produc- } \\
\text { ers, vendors, markets, and organizations in } \\
\text { the region. }\end{array}$ & $\begin{array}{l}\text { Effectively used network mapping to visualize } \\
\text { a database of information. }\end{array}$ \\
\hline $\begin{array}{l}2016 \text { Report on the } \\
\text { Economic Impact of the } \\
\text { Moscow Farmers Market }\end{array}$ & $\begin{array}{l}\text { Bureau of Economic Analysis, EMSI, } \\
\text { IMPLAN, vendor surveys, community } \\
\text { surveys, business surveys. }\end{array}$ & $\begin{array}{l}\text { The report provides a range of estimated } \\
\text { economic impacts, utilizing different scenarios } \\
\text { and/ or assumptions, providing the reader with } \\
\text { a range of estimated impacts, effectively } \\
\text { incorporates opportunity costs by assuming } \\
\text { only a portion of farmers market sales are } \\
\text { assumed to be "new" spending in the region. }\end{array}$ \\
\hline
\end{tabular}


a better understanding of individual components of the Palouse-Clearwater regional food system, but did not integrate or coordinate with the other efforts listed.

Feasibility Study: L atah C ounty F ood Innovation and Resource C enter (2013)

The 2013 study conducted by a consulting firm used both primary and secondary data to assess the feasibility of establishing a food innovation and resource center. The report provides secondary data on the study area (including many visualizations of the study area using maps), the agricultural sector in the region, and a market analysis that focuses on demographics and food deserts. O ne example of a visual representation of the secondary data utilized in the study is a map (Figure 1) that uses the Level IV Ecoregions (U.S. Environmental Protection Agency, n.d.) to define the agriculturally productive (light green) and nonproductive areas (dark green) in the region (outlined in red). This map effectively communicates major differences in arable land that can be found across this diverse region, highlighting the need for food systems development strategies that are suited to this diversity. The map, however, stops short of estimating the supply of various commodities that could be grown, as Swenson (2011) did in the case study highlighted in the Toolkit.

Primary data was collected through a producer survey that targeted food producers, processors, and other sellers, and through a purchaser survey that targeted large-volume buyers. These two surveys aimed to determine the market potential for a food innovation and resource center. The project followed the Toolkit's protocol to contact survey participants first via letters and emails. The letters and emails invited producers and purchasers to attend a regional food hub meeting and informed them they would be receiving an email

Figure 1. Level IV Ecoregions with Significant Growing Capacity

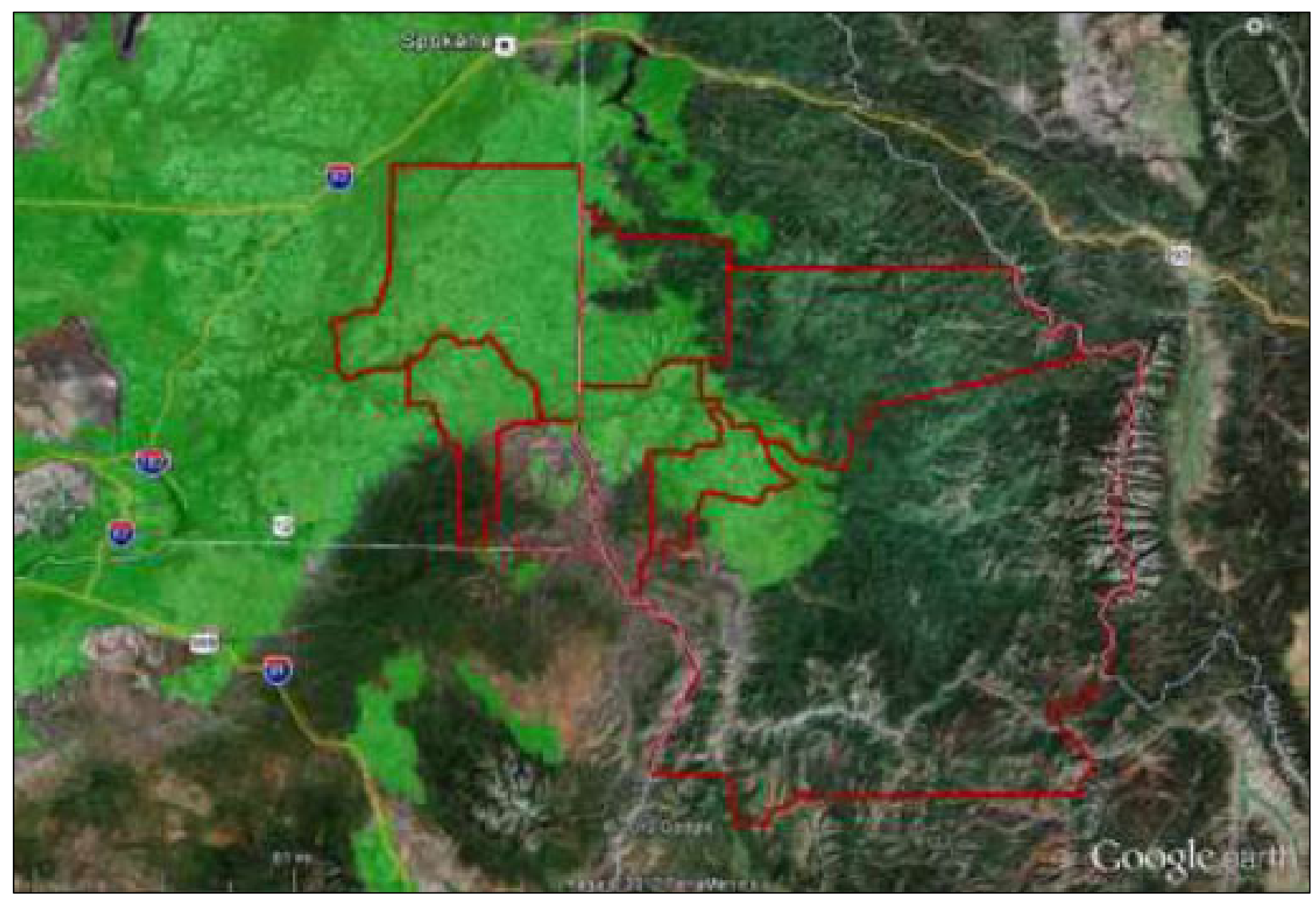

Source: Earth (Manheim Solutions, Inc. \& Watson Regional Economic Network, 2013). 
asking them to participate in an anonymous survey (if they were a producer) or to participate in an interview (if they were a buyer). Responses to the buyer email survey were poor, and in discussions with peers at food systems meetings, the team learned this was a common challenge across food system assessments. Researchers were able to get a better response by supplementing their initial efforts to reach out by letters or email with phone interviews, resulting in a response of 52 producers and 17 purchaser surveys. D ue to both time and resource constraints- a challenge that the Toolkit notes as a common challenge of primary data collection- respondents of the producer survey were not evenly distributed across the region nor across types.

D irect-to-C onsumer F ood M ark ets in the $\mathrm{N}$ orth $\mathrm{C}$ entral $\mathrm{H}$ ealth D istrict of Idaho (2014) In a 2014 study of direct-toconsumer markets in the region, secondary data was used to describe the natural, human, and cultural capital in the region (Schuette \& Merrell, 2014). D ata sources included the Idaho D epartment of Public Health and Welfare, USD A National Agricultural Statistical Service (USD A NASSS), Idaho Agricultural Statistics, local economic development associations, the U.S. Census Bureau, the Idaho Office of Economic Development, and city-level comprehensive plans. Following recommendations of the Toolkit, the study used a combination of local- and nationallevel secondary data sources to tell the story of their region. Specifically, the national data allowed for a standardized set of measures that enabled the study area to compare itself to other regions. Although they would likely tell the richest story, in many cases local data are not as thorough or inclusive as a researcher may need to understand the "whole picture." So, using all available secondary data from the local level augmented with national-level data where needed is a good way to effectively tell the story of a region, and illustrate where the region varies from the broader U.S., all without having to collect primary data.

F ood Security in the N orth Central H ealth D istrict of Idaho (2014)

In a 2014 study of food security in the region, a food security index was created at the zip-code level (Figure 2) (Schuette, Laninga, \& Merrell, 2014) using data from the U.S. Census Bureau's American Community Survey. The index compiled

Figure 2. Food Security in the North Central Health District of Idaho

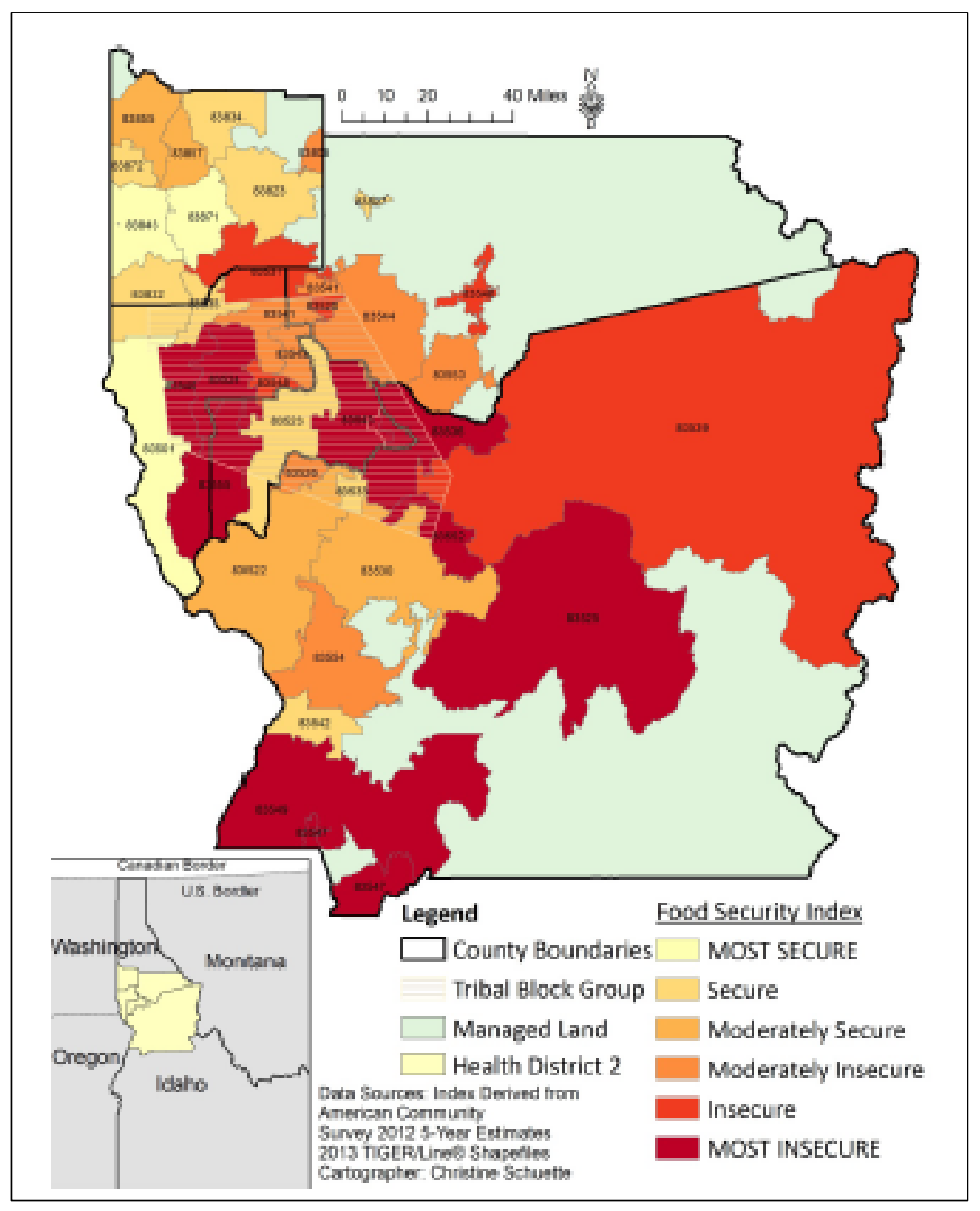

Source: Schuette, Laninga \& Merrell (2014). 
demographic characteristics (population, median age, income, poverty, labor force participation, unemployment rates, health insurance coverage, participation in the Supplemental Nutrition Assistance Program [SNAP, often referred to as food stamps]). To incorporate food access, the study used data from InfoUSA on grocery retail outlets and from the USD A's SNAP Retailer Locator to determine SNAP-approved retail outlets.

In addition to utilizing secondary data, the researchers collected primary data, which assessed stakeholder perceptions of food security in the region and asked both closed- and open-ended questions via online surveys. Stakeholders include members of community-based organizations, the faith community, farmers, processors, distributors, and individuals working in government, health care, and education. The results from primary data collection were used to provide more nuanced local policy context to the conclusions drawn from secondary data analysis.

E x tensive D atabase of $\mathrm{F}$ ood Producers, $\mathrm{V}$ endors, $M$ ark ets, and 0 rganizations Induding Interconnections of W ho Sells to W hom (2013, Current) The Coalition has also collected primary data to create an extensive database of food producers, vendors, markets, and organizations, along with geographic coordinates for buyers and sellers (Helbling \& Hall, 2015). This database was created in 2013 and is being updated through telephone calls, web searches, and physical site visits by the University of Idaho community food systems area extension educator and a part-time intern, as well as through ongoing conversations with Coalition members. The data in this database was originally intended to be used to create a systems graphic of food flow (Figure 3). Completed before the Toolkit was available, this graphic may be overly complex and requires considerable study to understand the magnitude of the food system sectors and processes it represents. It may also have been framed differently if examples from the Toolkit, such as the Maryland food system map in module 3, had been available when it was being created.
2016 Report on the E conomic Impact of the M oscow Farmers Mark et In 2016, the city of Moscow, Idaho, sponsored a study to determine the economic impact of the Moscow Farmers Market (Peterson \& Pool, 2016). Secondary data for the analysis was compiled from the Bureau of Economic Analysis, EMSI (a Moscow-based private economic data provider), and IMPLAN (an economic impact data platform). Primary data were collected utilizing three Rapid Market Assessments 2 (RMAs) surveys and three market analyses ${ }^{3}$ - a Sticky E conomy Evaluation D evice (SEED), a Neighborhood Exchange Evaluation D evice (NEED), and a Food Environment Evaluation D evice (FEED). The RMAs captured customer spending at the Moscow Farmers Market and at downtown businesses adjacent to the market on specific market days using dot surveys. The SEED , NEED, and FEED analyses utilized a combination of in-person interviews, mail surveys, and online surveys to collect data on market sales, customer interests, and market impacts on downtown businesses.

All the data collected on the farmers market were compiled and utilized, in combination with IMPLAN, to conduct the economic impact study. At the community level, the Coalition gained analytical capacity when Steven Peterson from the University of Idaho's College of Business and Economics joined the assessment team, bringing his expertise to estimate the economic impact of specific businesses or initiatives, such as the Moscow Food Co-op and Moscow Farmers Market. The Toolkit's clear explanation of impact analysis helped Coalition members understand and explain Peterson's economic impact results to nonacademic and non-economist audiences.

The report provides a range of estimated economic impacts, utilizing different scenarios and assumptions. Because there are often multiple ways to evaluate the economic impacts of a local food system, a scenario approach provides the reader with a range of estimates from which to choose. The first scenario (\#1) estimates market economic impacts based on consumer spending as reported

$2 \underline{\text { http:/ / smallfarms.oregonstate.edu/ sites/ default/ files/ small-farms-tech-report/ eesc 1088-e.pdf }}$

3 http:/ / marketumbrella.org/ 
Journal of Agriculture, Food Systems, and Community D evelopment ISSN : 2152-0801 online https:/ / www.foodsystemsjournal.org

Figure 3. Palouse-Clearwater Bioregion Food Network Map

Palouse-Clearwater Bioregion Food Network Map

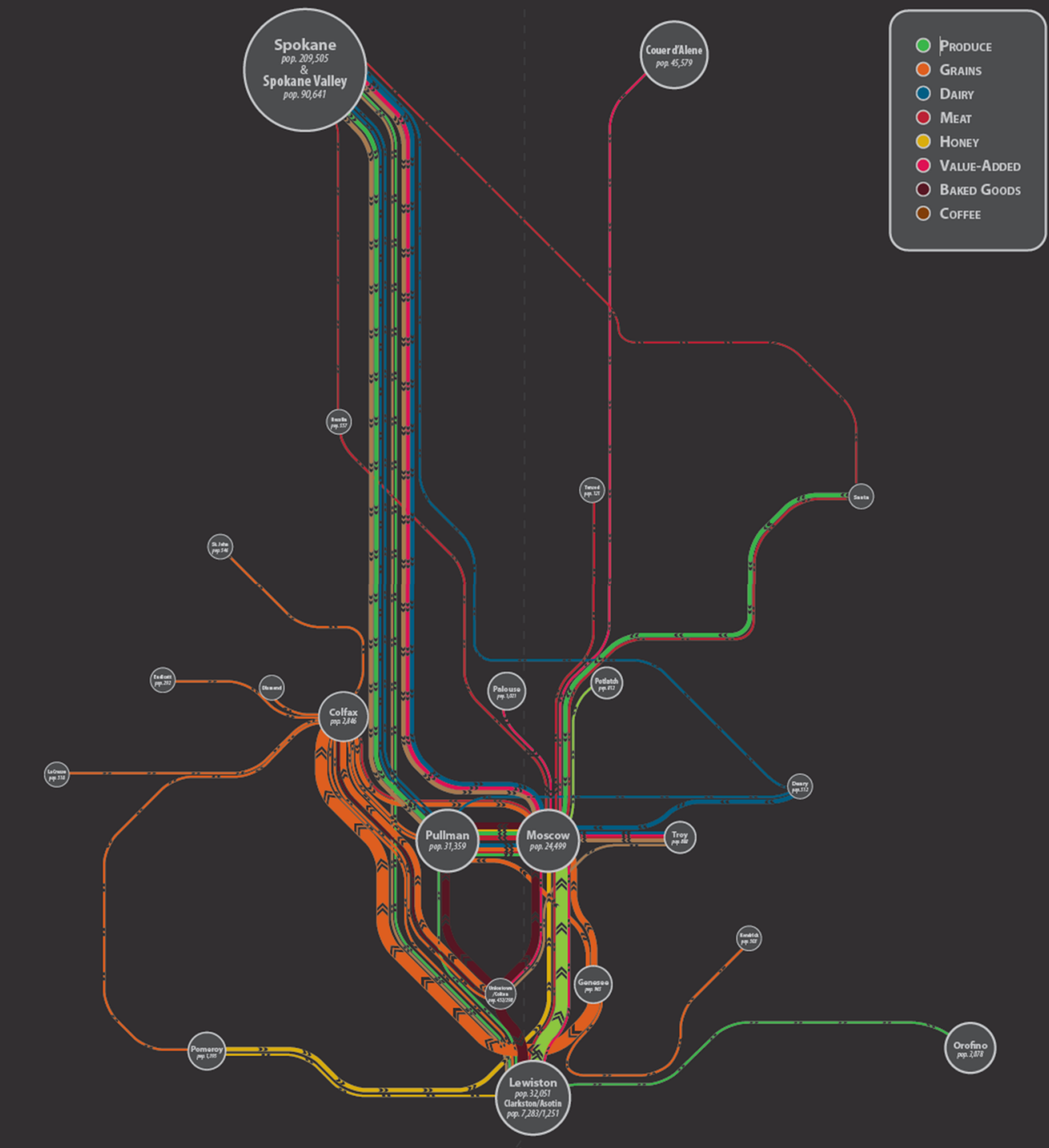

Producers and Markets by City

Asotin, WA
Wild Canyon Organics

Endicott, WA
O R\&R Farms

Clarkston, WA

O Bronzestone Dipping Company

O Hay's Produce \& Garden Center

O Wilson Banner Ranch

Coeur d'Alene, ID

Colfax, wA
Danaher Farms

O Joseph's Grainery

Colton, WA

O Druffel Farms

Deary, ID

O Brush Creek Creamery

Three Sisters Egg-ny

Diamond, WA Huntley Family Joint Venture

O R \& R Farms
Genese, ID
O Blune Farms
O Jen Crops
O Odberg Farms
O Pacific Northwest Farmers Coop
O Rattlessake Ranches
O Rim Rock Ranches
O Zenner Family Farm
Lacrosse, WA
O Western CFarms
Lewiston, ID
O Harvest Ridge Organics
Moscow, ID
O Affinity Farms
O C \&LLocker
O Deep Roots Farm
O Flying DW Ranch

O FosBizGardens Jim's Year Round Produce

Marylane's Farm

Moscow Urban Farm Company

Panhandle Artisan Bread Co.

Ravenscroft Farm

Sisters' Cookie Company

Twin Mountain Organic

U ofl Organic Farm

Woodland Apiaries

Woodland Apiaris

Orofino, ID

Palouse, WA

O Noah's Ark Food:

Pomeroy, WA

Garuso's Honey compa
Potlatch, ID

Fiddler's Ridge Farm

Pullman, WA

Ferdinand's lce Cream
Omache Farms

O Palouse Brand

O Steve \& Kevin Mader GP

O WSU Creamery

O WSU Organic Farm

Rosalia, WA

O Palosue Pastured Poultry

Santa, ID

O Pokey Creek Farm

O Tamarack Yaks

Spokane Valloy, WA

O Bumble Bar
Spokane, WA

C Cravens Coffee Comp

O Spokane Family Farm

O Victor's Hummus

St. John, WA

0 Cherry Creek Ranch

Troy, ID

Iroy, ID

O Little Bear Dairy

Palouse Prarie Farms

O Sticky Fingers Farm

Uniontown, WA

O Grandma Lela's Confectionery

OSage Baking Company

Source: Helbling \& Hall (2015). 
by vendor surveys. This is the most conservative measure of economic impacts, as vendors typically underreport sales, and the survey data do not include all vendors at the market. The second scenario (\#2) estimates the economic impacts generated from brick-and-mortar businesses and other spinoffs that resulted from the existence of the farmers market. In Moscow, the farmers market acts as a business incubator, serving as the starting point for numerous new entrepreneurs in the city. The assumption of this scenario is that without the farmers market, these businesses would not exist, and subsequently, all of their economic activity could be attributed to the Moscow Farmers Market.

The third scenario (\#3) estimates market economic impacts based on the RMA and SEED surveys conducted on customers, in which they estimated total spending at the market. Estimates are provided for high and low scenarios because there were differing survey results due to different sampling and collection techniques. The assumption in this scenario is that customer surveys conducted at the market provide a more accurate picture of total spending than do producer surveys.

The final scenario (\#4) integrates the economic impact of customer spending that spills over beyond the farmers market vendors to adjacent businesses in downtown Moscow. As was the case in the previous scenario, high and low scenario estimates were provided. D ata for this scenario were also generated from RMA and SEED surveys in which farmers market customers were asked if they planned on doing additional shopping or eating downtown that day and, if yes, how much they anticipated spending. Author Peterson made assumptions regarding which sectors received this spending (due to missing data). Predefined margins from IMPLAN were used for all value-added and craft sales, following the Toolkit's best practices.

The Toolkit gives clear advice on how important the geographic scope of the analysis and market area are for providing valid estimates. Peterson's analysis aligned with the Toolkit's advice. Based on survey data, the author assumed that $35 \%$ of the market visitors come from outside of Latah County and 15\% of market visitors would have spent their money outside the county in the absence of the farmers market (i.e., they would have gone outside the region for shopping trips). These assumptions mean that $50 \%$ of the customers that visit the market represent "new" spending in Latah County (and thus are appropriate to include in the economic impact estimate). This is an example of how to account for opportunity costs, as discussed in Chapter 6 of the Toolkit. By assuming that only $50 \%$ of farmers market sales can be attributed to the economic impact of the farmers market itself, the authors are careful to consider the fact that many of the shoppers at the Moscow Farmers Market otherwise would have simply spent their money at another retail outlet in Latah County. This would result in a net impact closer to zero than if these were truly new flows into the economic system of the area.

The results presented in Table 2 include direct, indirect, and induced impacts to jobs, wages and salaries, and output from the Moscow Farmers Market for each of the scenarios described above as well as total tax impacts. Total economic impacts when all scenarios are included range from US\$3.9 million to US\$5.5 million in output (with multipliers ranging from 1.2 to 1.4), 94 to 129 local jobs, and US\$290,000 to US\$405,000 in taxes generated in the state. The author conducted a robustness check on the reliability of the results by comparing tax results to average tax payments per job in Latah County, based on taxpayer data.

The study provides evidence that the market has a positive impact on the downtown community of Moscow due to direct sales at the market and sales at nearby downtown businesses. Moreover, there is evidence that the market fosters the brick-and-mortar businesses that may develop as a spillover effect of business-to-business activity with market vendors. By including ranges of estimates and utilizing transparent, sound assumptions, this study adopts and highlights one of the Toolkit's best practices. Results from this study documented the value of the city of Moscow's investment in the farmers market to the Moscow Farmers Market Commission and city council, which led to the city moving management of the farmers market out of the city's arts department and funding a full-time community events and farmers market coordinator. 
Table 2. Economic Impacts of Moscow Farmers Market (Low and High Estimates), Includes the Direct, Indirect and Induced Impacts

\begin{tabular}{|c|c|c|c|}
\hline \multicolumn{4}{|c|}{ Low Estimate } \\
\hline Category & Jobs & Wages/ Salaries (US\$) & Output (US\$) \\
\hline \#1: Vendor Expenditures & 15 & $\$ 266,434$ & $\$ 557,787$ \\
\hline \#2: Brick and Mortar/Spinoffs & 54 & $\$ 944,643$ & $\$ 2,278,578$ \\
\hline \#3: Visitor Spending Market (Net) & 12 & $\$ 221,977$ & $\$ 518,194$ \\
\hline \#4: Visitor Spending Downtown & 13 & $\$ 251,538$ & $\$ 585,701$ \\
\hline Total & 94 & $\$ 1,684,591$ & $\$ 3,940,260$ \\
\hline \multicolumn{4}{|c|}{ High Estimate } \\
\hline Category & Jobs & Wages/ Salaries (US\$) & Output (US\$) \\
\hline \#1: Vendor Expenditures & 15 & $\$ 266,434$ & $\$ 557,787$ \\
\hline \#2: Brick and Mortar/Spinoffs & 54 & $\$ 944,643$ & $\$ 2,278,578$ \\
\hline \#3: Visitor Spending Market (Net) & 33 & $\$ 624,164$ & $\$ 1,454,681$ \\
\hline \#4: Visitor Spending Downtown & 26 & $\$ 503,075$ & $\$ 1,171,401$ \\
\hline Total & 128 & $\$ 2,338,316$ & $\$ 5,462,477$ \\
\hline \multicolumn{4}{|c|}{ Tax Impacts } \\
\hline & Local (US\$) & State (US\$) & Total (US\$) \\
\hline Low Scenario & $\$ 92,865$ & $\$ 195,164$ & $\$ 288,029$ \\
\hline High Scenario & $\$ 131,692$ & $\$ 273,343$ & $\$ 405,035$ \\
\hline
\end{tabular}

Source: Peterson \& Pool, 2016: Note: Across the scenarios, the author uses similar assumptions.

\section{Lessons Learned and N ext Steps}

While the Coalition has conducted extensive data collection on its food system, previous studies were not coordinated within a larger, umbrella assessment with a specific set of goals. Given the piecemeal nature of the studies, they do not tell a cohesive story of the food system; in short, the sum of all parts is not greater than the whole. Without a systematic process of framing, team-building, defining a unified priority, and goal-setting, the resources secured to assess this region were not effectively invested to build a comprehensive understanding of the Palouse-Clearwater food system and did not result in a unified action plan for further food system development.

When the Toolkit was released in 2016, the Coalition's steering committee discussed how it could help the Coalition better organize its existing food system data, find a greater set of secondary data that could be integrated with the primary findings, and guide the Coalition through a more systematic and rigorous economic assessment of the food system. Utilizing the ideas presented in the Toolkit, the Coalition embarked on an effort to expand its baseline assessment of the local food system. This set the stage for future updates of the economic contributions of specific food system businesses and initiatives, as well as for assessment plans that will use relevant criteria and data to evaluate changes in the Palouse-Clearwater food system. Specifically, the Coalition began using the Toolkit and its basic tenets of an economic impact assessment to evaluate future actions. These include (1) defining and communicating what constitutes economic impact within the construct of a local food system, (2) understanding how economic impact data can help identify leverage points in the local food system, (3) building an understanding of the real and potential economic impacts of local food system components or sectors, and (4) using that information to strategically acquire and invest resources in food system projects and research that will most likely strengthen the economic viability of the region. 
As a first step in the Coalition's assessment, members began working together to compile all relevant data from previous assessments for review by the steering committee and key Coalition members. However, changes in Coalition leadership over that period disrupted the momentum on the economic assessment. At the same time, multiple career changes, program redirections, and staff changes in key leadership roles in member organizations have stalled the community process. And although Coalition is fortunate to have a great deal of historical data collected by different groupsespecially students in University of Idaho courses and AmeriCorps VISTA members - the quality and context of collected data may limit its value as a true baseline.

As the Coalition's leadership recoalesces, the economic impact study of the Moscow Farmers Market is being updated and an economic impact of the Moscow Food Co-op (Peterson, 2017) is being completed. The Coalition's expectation is that these economic impact assessments on individual components of the food system will help to engage a broader stakeholder group, including city staff, economic development professionals, elected officials, and downtown businesses. If the studies effectively demonstrate the positive economic spillovers associated with these markets, food system development may become a higher priority among community leaders. In turn, more holistic, systemwide assessment and planning may occur. Finally, several other assessments are taking place within the Coalition's region, including a food security assessment in Whitman and Latah counties, a Nez Perce Tribal food sovereignty assessment, and a newly funded AFRI small farms research project. As in the past, there is no cohesive coordination among these studies. The Coalition's initial interest in how to use the Toolkit to make use of the existing data and then to move forward in understanding change in the Palouse-Clearwater food system over the past 5 to 6 years has only been partially effective. However, lessons learned through this process improve the Coalition's chances for future coordination and integration of regional assessment efforts. In the process of using the Toolkit to assess its past studies, the Coalition has clarified its goals for assessing economic impact and gained a deeper understanding of the need for systematic planning and assessment processes. The Coalition's goals of making meaningful use of existing data and studies and comparing existing, baseline data with the 2017 Census of Agriculture data that will be available soon may provide an opportunity for the team to reassemble and rebuild momentum. Y et some challenges remain. To be successful in creating a comprehensive understanding of the PalouseClearwater food system, the Coalition will need to find committed leadership and sufficient resources to follow best practices outlined by the Toolkit. Without a more holistic understanding of the Palouse-Clearwater food system, Coalition members may not effectively identify leverage points for strengthening its regional food system. An important lesson learned from this case study is that the Coalition and its peer community-based organizations across the country need to develop clear assessment goals, establish a commitment to the assessment process within member organizations, and secure the resources necessary to complete an integrated assessment process. Beyond gathering data and conducting analysis, a team of community leaders and experts needs to commit the energy and time to build long-term capacity and increase community engagement in order to turn that data into actionable projects that will enhance the regional food system.

\section{References}

Helbling, J., \& Hall, S. (2015). Palouse-Clearwater Bioregion F ood N etwork Map. Printed copy available from University of Idaho, Moscow, ID.

Manheim Solutions, Inc., \& Watson Regional Economic Network. (2013). F easibility study: L atah C ounty F ood Innovation and Resource $\mathrm{C}$ enter. Prepared for the Latah County Economic D evelopment Council FIRC Working G roup and the Clearwater Economic D evelopment Association. Retrieved from http:/ / www.latahedc.org/ wpcontent/ uploads/ 2013/ 04/ Latah-County-FIRC-Feasibility-Study-Report-Reduced-Size.pdf 
Peterson, S. (2017, April). 2017 Report on the E conomic Impact of the M oscow F ood C 0-op. Presentation at the Moscow Food Co-op Annual Meeting, Moscow, Idaho. Retrieved March 1, 2018, from http:// www.moscowfood.coop/ boardnews/

Peterson, S., \& Pool, S. (2016). 2016 Report on the economic impacts of the M oscow Farmers M ark et: A ollaborate project from the City of M oscow. Retrieved February 1, 2018, from http:/ / www.ci.moscow.id.us/ documentcenter/ view/ 364

Schuette, C., Laninga, T., \& Merrell, G. (2014). F ood seaurity in the N orth C entral H ealth D istrid of Idaho. Special Report. University of Idaho O ffice of Economic D evelopment.

Schuette, C., \& Merrell, G . (2014). D irect-to-consumer food mark ets in the N orth Central H ealth D istrict of Idaho. Special Report. University of Idaho O ffice of Economic D evelopment.

Swenson, D . (2011). The regional economic development potential and onstraints to local foods development in the Midwest. Ames: Leopold Center for Sustainable Agriculture, Iowa State University. Retrieved from https:// core.ac.uk/ download/pdf/ 6857680.pdf

Thilmany McFadden, D ., Conner, D., D eller, S., Hughes, D ., Meter, K., Morales, A., ... Tropp, D . (2016). The economics of local food systems: A toolk it to guide community discussions, assessments, and choios. U.S. D epartment of Agriculture, Agricultural Marketing Service. Retrieved from www.ams.usda.gov/ sites/ default/ files/ media/ EconomicsofLocalFoodSystemsToolkit.pdf

U.S. Environmental Protection Agency. (n.d.). L evel III and IV E oregions by E PA Region. [Interactive map]. Retrieved February 1, 2018, from https:// www.epa.gov/ eco-research/ level-iii-and-iv-ecoregions-epa-region 